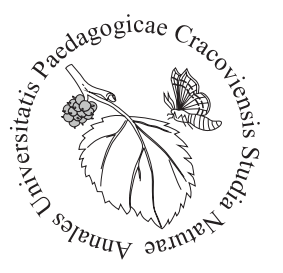

Peiman Zandi', Beata Barabasz-Krasny², Alina Stachurska-Swakoń3, Joanna Puła4 , Katarzyna Możdżeń2*

${ }^{1}$ Institute of Environment and Sustainable Development in Agriculture, Chinese Academy of Agricultural Science, Beijing 100081, P. R. China

${ }^{2}$ Institute of Biology, Pedagogical University of Cracow, Podchorążych 2, 30-084 Kraków, Poland, *katarzyna.mozdzen@up.krakow.pl ${ }^{3}$ Institute of Botany, Jagiellonian University, Gronostajowa 3, 30-387 Kraków, Poland ${ }^{4}$ Faculty of Agriculture and Economics, University of Agriculture, Mickiewicza 21, 31-120 Kraków, Poland

\title{
Allelopathic effects of Stellaria media (L.) Vill. on germination and early stages of growth of Raphanus sativus var. radicula
}

\section{Introduction}

Chickweed (Stellaria media (L.) Vill., Caryophyllaceae) is a cosmopolitan plant species known as a particularly troublesome weed in field crops and gardens. The plant may produce several generations of seeds throughout the year. The seeds could germinate at low temperatures and they are long-lived. The greatest damage by the species to crops is noticed at seedling stage of the crop plants due to the competition for soil nutrients and light. Chickweed germinates and grows fast and causes the shading of crop seedlings (Turkington et al., 1980). The high specialisation of chickweed as a crop weed results from the necessity to develop mechanisms that allow it to survive in unfavourable conditions. S. media produces a lot of chemical compounds, including the following: apigenin and its C-glycosides (Bouillant et al., 1984; Dong et al., 2007), vitexin (Ma et al., 2012), isovitexin (Budzianowski et al., 1991), luteolin glycosides, orientin, isoorientin (Hu et al., 2009), isoscutellarein C-glycoside (Yasukawa et al., 1982) and chrysoeriol C-glycoside (Sharma, Arora, 2012). There has been only one reference about the presence of isoflavonoids in the Stellaria genus (Kitanov, 1992) and a second concerning an isoflavonoids in another representative of the Caryophyllaceae family (Liu et al., 2007). The presence of O-glycosides of apigenin, luteolin, and other aglycones, and glycosides was also documented (Mikšátková et al., 2014).

Radish (Raphanus sativus L. var. radicula Pers., Brassicaceae) is an edible root vegetable well-known and popular throughout the world. Probably, it originates from Southeast Asia, and it was known for Greek and Roman agriculturalists of the first 
century AD. It has numerous cultivars, varying in size, flavour, colour, and length of time they take to mature. Radishes owe their sharp flavour to the various chemical compounds produced by the plants, including glucosinolate, myrosinase, and isothiocyanate (Kunachowicz et al., 2017).

The aim of the experiment was to investigate the allelopathic effect of aqueous extracts from aboveground organs of Stellaria media on germination, the early stages of growth and electrolyte leakage through cell membranes of radish (Raphanus sativus var. radicula) that are commonly cultivated in Poland three cultivars: 'Rowa', 'Krakowianka', and 'Półdługa'.

\section{Material and methods}

Fresh aboveground parts of chickweed (Stellaria media (L.) Vill.) were collected in nature from the the southern part of Poland (Suchoraba 49 $58^{\prime} 37^{\prime \prime} \mathrm{N} 20^{\circ} 11^{\prime} 49^{\prime \prime} \mathrm{E}$ ). The seeds of radish were purchased in the ordinary market from POLAN co. Three common cultivars of radish were used in the experiment: 'Rowa', 'Krakowianka', and 'Półdługa'.

The aqueous extracts from fresh aboveground organs of $S$. media in the form of decoction, infusion, and macerate were prepared according to Czerwińska et al. (2015). The seeds of radish cultivars were rinsed under running and distilled water and placed on sterile $9 \mathrm{~cm}$ Petri dishes (100 seeds per dish, in 5 repetitions with 2 series). They were placed in a growth chamber at constant temperature conditions of $20^{\circ} \mathrm{C}$, a relative humidity of about $90 \%$, with 12 -hour periods of light intensity for 8 days. During the experiment, seeds were watered with adequate aqueous extract from $S$. media every day and the control group was watered with distilled water. The same content of extract or water was always used. The experiment was repeated five times with two series.

The germination rate of radish seeds, seedling lengths, the fresh and dry mass of seedlings, and the degree of destabilisation of cell membranes were determined. The number of germinated seeds was counted every $24 \mathrm{~h}$. Based on the results, the germination rate was calculated: the number of germinated seeds/total seeds number for the germination experiment $\times 100 \%$. The average speed of germination was measured according to Chapisuio et al. (1997). The seedling length was measured at the end of the experiment as mean of lengths of whole seedlings $(\mathrm{cm})$ and as the length of underground and aboveground parts. After eight days, the fresh and dry mass of seedlings was determined. The degree of the destabilisation of cell membranes was determined using the method described as in Skrzypek et al. (2015), Barabasz-Krasny et al. (2017; 2018). 
The significance of differences were examined with inter-facility parametric statistical test - ANOVA (test one, simple), using Duncan's test (HSD) for homogeneous groups, at the level of $\mathrm{p}<0.05$. The calculations were performed using Statistica 13.0 from StatSoft, Inc. (2018) for Windows.

\section{Results and Discussion}

The common opinion that plants considered to be weeds are harmful, unwanted, and should be removed from the crops as soon as possible is not entirely true. Wild plants create perfect conditions for the life of many insects and other organisms. Biodiversity is conducive to maintaining the proper balance in the environment and prevents pest gradation. Some weed species are indicators of the soil type and soil conditions and can serve as soil cover against erosion during winter. Weeds could produce different chemical compounds that could stimulate or inhibit the development or growth of various organisms (Skrzypek et al., 2015) and could be also used in organic farming. In the light of the mentioned significance of the weeds, studies on the biology of crop weeds and their interaction with crop species are desirable and important.

Tab. 1. Cumulative percentage of seed germination of Raphanus sativus L. var. radicula Pers. cultivars: 'Rowa', 'Krakowianka', and 'Półdługa' under influence of Stellaria media (L.) Vill. aqueous extracts

\begin{tabular}{|c|c|c|c|c|c|c|c|c|}
\hline \multirow{2}{*}{ Treatment } & \multicolumn{8}{|c|}{ Time of germination [day] } \\
\hline & 1 & 2 & 3 & 4 & 5 & 6 & 7 & 8 \\
\hline \multicolumn{9}{|c|}{ 'Rowa' } \\
\hline Control & 15.80 & 26.00 & 74.40 & 95.60 & 99.60 & 99.60 & 99.60 & 99.60 \\
\hline decoction & $7.40^{*}$ & 15.00 & $30.60^{*}$ & $48.40^{*}$ & $55.00^{*}$ & $57.80^{*}$ & $59.60^{*}$ & 62.60 \\
\hline infusion & 27.80 & $54.00^{*}$ & 70.20 & 81.80 & 86.40 & 90.40 & 90.80 & 91.40 \\
\hline macerate & $8.00^{*}$ & 30.20 & $33.00^{*}$ & $37.60^{*}$ & $41.00^{*}$ & $42.40^{*}$ & $45.00^{*}$ & $45.40^{*}$ \\
\hline \multicolumn{9}{|c|}{ 'Krakowianka' } \\
\hline Control & 79.80 & 90.00 & 97.00 & 98.00 & 98.40 & 98.60 & 99.80 & 100.00 \\
\hline decoction & 86.60 & 95.00 & 98.20 & 99.00 & 99.80 & 99.80 & 99.80 & 99.80 \\
\hline infusion & 72.20 & 94.00 & 95.00 & 95.40 & 95.40 & 95.40 & 95.40 & 95.40 \\
\hline macerate & 69.80 & 71.60 & 73.80 & 76.40 & 78.80 & 79.60 & 79.60 & 79.60 \\
\hline \multicolumn{9}{|c|}{ 'Półdługa' } \\
\hline Control & 24.80 & 40.40 & 45.60 & 66.80 & 95.80 & 99.60 & 99.80 & 100.00 \\
\hline decoction & $10.80^{*}$ & 35.20 & 44.60 & 55.40 & $58.60^{*}$ & 66.40 & 70.00 & 75.25 \\
\hline infusion & $12.40^{*}$ & 37.40 & 44.00 & $45.80^{*}$ & $54.00^{*}$ & 60.60 & $63.60^{*}$ & $66.20^{\star}$ \\
\hline macerate & 23.00 & 52.20 & $59.20^{*}$ & 63.80 & 65.80 & 68.80 & 71.20 & 71.20 \\
\hline
\end{tabular}

Values * differ significantly according to Duncan's test $\mathrm{p}<0.05$

In the presented experiment, the germination rate of radish seeds watered with extracts from S. media was lower than the control group, independently of the type 
of used extracts. The highest germination rate and capacity for 'Krakowianka' cultivar on decoction, and the lowest for 'Rowa' on macerate were observed (Tab. 1-2). The inhibition of germination could be attributed to the biochemical effects caused by the extracts. For example, Jezierska-Domaradzka and Kuźniewski (2007), in biotests, showed that $2.5 \%$ of $S$. media extracts negatively affected Origanum majorana L. and Ocimum basilicum L.

The growth of 'Rowa' and 'Krakowianka' seedlings (measured as length) was stimulated by infusion and slightly inhibited by decoction and macerate. The growth of 'Półdługa' seedlings was inhibited by each of the extracts, relative to the control group (Fig. 1). The lack of negative effects of the extracts on seeds germination was most likely caused by the low concentration of allelopathic substances (Duer, 1996).
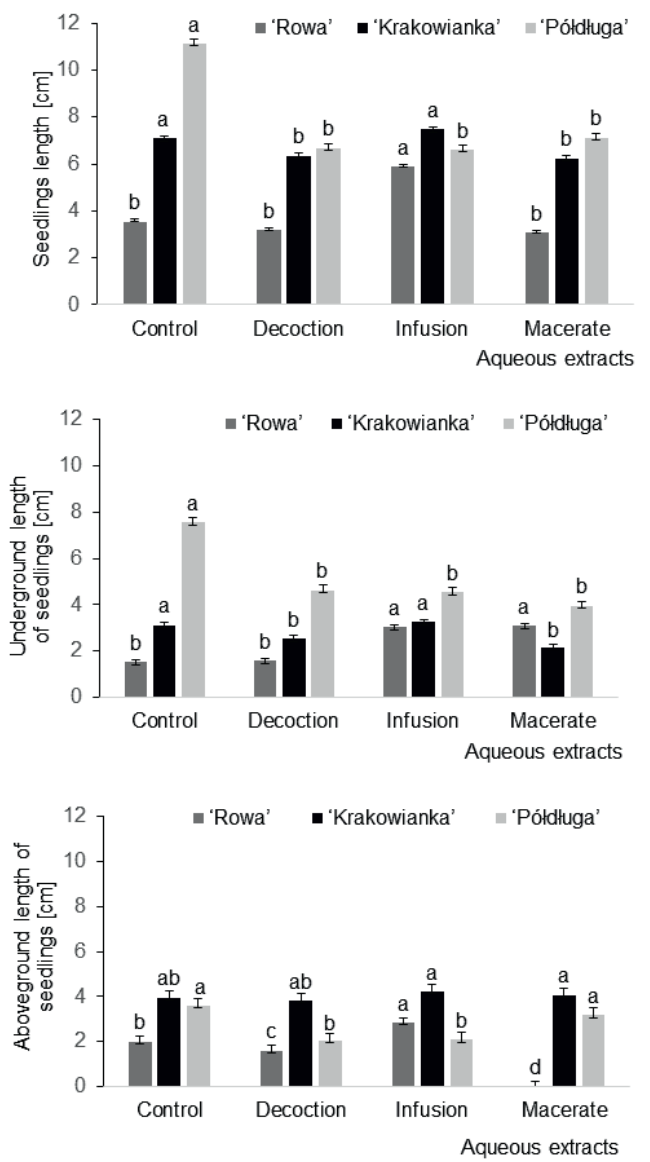

Fig. 1. The length of seedlings (whole, underground, aboveground parts) Raphanus sativus L. var. radicula Pers. cultivars: 'Rowa', 'Krakowianka', and 'Półdługa' under influence of Stellaria media (L.) Vill. aqueous extracts. Values a, b, c differ significantly according to Duncan's test $\mathrm{p}<0.05$ 
Tab. 2. Average speed of germination Raphanus sativus L. var. radicula Pers. cultivars: 'Rowa', 'Krakowianka', and 'Półdługa' under influence of Stellaria media (L.) Vill. aqueous extracts

\begin{tabular}{|c|c|c|c|c|c|c|c|c|}
\hline \multirow{2}{*}{ Treatment } & \multicolumn{8}{|c|}{ Time of germination [day] } \\
\hline & 1 & 2 & 3 & 4 & 5 & 6 & 7 & 8 \\
\hline \multicolumn{9}{|c|}{ 'Rowa' } \\
\hline Control & 37.40 & 35.98 & 68.24 & 80.33 & 79.68 & 74.70 & 74.70 & 66.40 \\
\hline decoction & 20.70 & $19.76^{*}$ & $30.80^{\star}$ & $41.92^{*}$ & $44.61^{\star}$ & $43.50^{*}$ & $44.95^{\star}$ & $41.73^{\star}$ \\
\hline infusion & 45.20 & 52.98 & 63.34 & 69.32 & 69.70 & 67.83 & 68.15 & 60.93 \\
\hline macerate & $18.58^{*}$ & 28.23 & $29.83^{*}$ & $32.25^{*}$ & $33.14^{*}$ & $32.02^{*}$ & $33.78^{*}$ & $30.27^{*}$ \\
\hline \multicolumn{9}{|c|}{ 'Krakowianka' } \\
\hline Control & 85.51 & 80.45 & 83.47 & 81.86 & 78.82 & 74.05 & 74.87 & 66.67 \\
\hline decoction & 90.56 & 83.99 & 84.41 & 82.63 & 79.84 & 74.85 & 74.85 & 66.53 \\
\hline infusion & 79.82 & 82.51 & 81.50 & 79.50 & 76.32 & 71.55 & 71.55 & 63.60 \\
\hline macerate & 72.21 & 63.79 & 64.10 & 64.13 & 63.15 & 59.70 & 59.70 & 53.07 \\
\hline \multicolumn{9}{|c|}{ 'Półdługa' } \\
\hline Control & 43.09 & 43.01 & 46.65 & 60.84 & 77.17 & 74.72 & 74.87 & 66.67 \\
\hline decoction & $27.09^{*}$ & $35.34^{*}$ & 41.80 & 47.83 & $48.36^{*}$ & 50.10 & 52.94 & 50.17 \\
\hline infusion & $26.33^{*}$ & 36.02 & $39.88^{*}$ & $40.42^{*}$ & $44.36^{*}$ & $45.70^{*}$ & $47.92^{*}$ & $44.13^{*}$ \\
\hline macerate & 36.88 & 48.28 & 52.29 & 53.95 & 53.16 & 51.80 & 53.40 & $47.47^{*}$ \\
\hline
\end{tabular}

Values * differ significantly according to Duncan's test $\mathrm{p}<0.05$

The fresh mass of radish seedlings was lower in all used type of extract, compared to the control group. The exception was the 'Rowa' cultivar, for which the fresh mass increased on macerate. There were no statistical differences between the dry mass of 'Krakowianka' cultivar watered with extracts and distilled water. However, the dry mass of 'Rowa' and 'Półdługa' was lower than in the control group (Tab. 3). The products of the breakdown of glucosinolates can inhibit and delay seed germination by inhibiting seeds and protein synthesis in the seedlings (Leblová-Svobodová, Kostír, 1962). The lower effects on the germination rate and dry mass may be attributed to the low persistence of glucosinolate hydrolysis products in the soil (Haramoto, Gallandt, 2004).

Compared to the control, the $S$. media extracts decreased the electrolyte leakage through the cell membranes of all radish seedlings. The exception was the macerate, which, in the 'Rowa' cultivar, caused the increase of the destabilisation of cell membranes (Tab. 3). Lower membrane damage can be correlated with an increased capacity to accumulate sugars at the leaf level during stress (Bajji et al., 2000). In fact, it was hypothesized that sugars, particularly non-reducing disaccharides, interact with cellular membranes to increase the stability of the lipid layers (Nilsen, Orcutt, 1996). This may prevent lateral phase transition and the formation of lipid domains which have the potential of forming inverted micelles and thus increasing membrane leakage (Bajji et al., 2000). 
The different effect of $S$. media extracts on radish seeds may result from the various concentrations of chemical compounds contained in them (Mikšátková et al., 2014; Skrzypek et al., 2015; Barabasz-Krasny et al., 2017). According to Inderjit and Dakshini (1998), both young and adult chickweed species release soil-soluble phenols that inhibit plant growth. In addition, the size of tested seeds is important, because small seeds, such as radish, are more sensitive to the effects of allelopathic substances than larger seeds (Riece, 1984).

Tab. 3. Fresh and dry mass and electrolyte leakage of Raphanus sativus L. var. radicula Pers. cultivars: 'Rowa', 'Krakowianka', and 'Półdługa' under influence of Stellaria media (L.) Vill. aqueous extracts

\begin{tabular}{lccc}
\hline \multirow{2}{*}{ Treatment } & \multicolumn{3}{c}{ Name of cultivars } \\
\cline { 2 - 4 } & 'Rowa' & 'Krakowianka' & 'Półdługa' \\
\hline Control & 0.0832 & 0.1244 & 0.0872 \\
decoction & 0.0600 & 0.1104 & 0.0702 \\
infusion & 0.0766 & 0.1036 & $0.0690^{\star}$ \\
macerate & $0.1134^{*}$ & 0.1138 & 0.0866 \\
\hline & \multicolumn{3}{c}{ Dresh mass [g] } \\
\hline Control & 0.0068 & 0.0154 & 0.0090 \\
decoction & 0.0048 & 0.0114 & 0.0062 \\
infusion & 0.0066 & 0.0114 & $0.0054^{\star}$ \\
macerate & $0.0116^{\star}$ & 0.0114 & 0.0068 \\
\hline & & Electrolyte leakage [\%] & 37.89 \\
Control & 49.94 & 43.86 & 31.67 \\
decoction & 36.13 & $33.89^{*}$ & $31.31^{\star}$ \\
infusion & 38.79 & $34.05^{*}$ & $29.46^{\star}$ \\
macerate & 44.46 & &
\end{tabular}

Values * differ significantly according to Duncan's test $\mathrm{p}<0.05$

The use of an alternate crop is a basic, very effective, and well-known method that limits the occurrence of weeds in crop fields. A few-year-old cultivation of the same species or plants from the same group causes that the weeds accompanying these crops intensively increase their number and cover, increase the soil seed bank, and thus increase the cover in the field next year. On the other hand, cultivation of other species the following year could change the soil conditions; and as a consequence, the weeds from previous year could not have favourable conditions for germination and further development, or they die soon after germination (Sturm et al., 2016). It is also important to introduce new cultivars (or varieties) and check their resistance to allelopathic weeds. 
The aqueous extracts from fresh aboveground organs of Stellaria media (L.) Vill. have allelopathic potential. They can stimulate or inhibit germination and early stages of radish growth, depending on the form of extract and, as we suppose, the type and concentration of chemical compounds in extracts. The obtained results provide the basis for further studies on the allelopathic influence of chickweed on radish cultivars or other vegetables in further stages of their development.

\section{References}

Bajji, M., Lutts S., Kinet, J.M. (2000). Resistance to water stress in durum wheat: Comparison of cell and whole se edling behaviours. In: C. Royo, M.M. Nachit, N. Di Fonzo, J.L. Araus (eds.), Durum wheat improvement in the Mediterranean region: New challenges. Options Méditerranéennes, pp. 22-34.

Barabasz-Krasny, B., Możdżeń, K., Sołtys-Lelek, A., Stachurska-Swakoń, A. (2017). The allelopathic potential of Cirsium oleraceum (L.) Scop. into the fodder meadow plants. Notulae Botanicae Horti Agrobotanici Cluj-Napoca, 45(1), 255-261. DOI: 10.15835/nbha45110727

Barabasz-Krasny, B., Możdżeń, K., Sołtys-Lelek, A., Stachurska-Swakoń, A. (2018). Biological traits of Impatiens parviflora DC. under different habitat conditions. Notulae Botanicae Horti Agrobotanici Cluj-Napoca, 46(1), 277-285. DOI: 10.15835/nbha46110970

Bouillant, M.L., Dearce, F.F., Favrebonvin, J., Chopin, J., Zoll A., Mathieu, G. (1984). Structural determination of "6-C-diglycosyl-8-C-glycosylflavones and" 6-C-glycosyl-8-C-diglycosylflavones by mass-spectrometry of their permethyl ethers. Phytochemistry, 23, 2653-2657. DOI: 10.1016/S00319422(00)84119-9

Budzianowski, J., Pakulski, G., Robak, J. (1991). Studies on antioxidative activity of some C-glycosylflavones. Polish Journal of Pharmacology and Pharmacy, 43, 395-401.

Chiapusio, G., Sánchez, A.M., Reigosa, Roger, M., Pellissier, F. (1997). Do germination indices adequately reflect allelochemical effects on the germination process? Journal of Chemical Ecology, 23(11), 2445-2453. DOI: 10.1023/B:JOEC.0000006658.27633.15

Czerwińska, E., Szparaga, A., Deszcz, E. (2015). Estimation of effect of dressing in plant extracts on germination capacity of yellow lupine and field pea seed. In: Z. Spiak, M. Kozińska (eds.), Rolnictwo Agronomy. Zeszyty Naukowe Uniwersytetu Przyrodniczego we Wrocławiu, 612, 7-21.

Dong, Q., Huang, Y., Qiao, S.Y. (2007). Studies on chemical constituents from Stellaria media L. Zhongguo Zhong Yao Za Zhi, 32, 1048-1051.

Duer, I., (1996). Potencjał allelopatyczny biomasy niektórych gatunków chwastów w stosunku do siewek pszenicy ozimej (Triticum aestivum var. vulgare). Fragmenta Agronomica, 2(50), 7-56. [In Polish]

Haramoto, E.R., Gallandt, E.R. (2004). Brassica cover cropping for weed management: a review. Renewable Agriculture and Food System, 19, 187-198. DOI: 10.1079/RAFS200490

Hu, Y.M., Wang, H., Ye, W.C., Qian, L. (2009). New triterpenoid from Stellaria media (L.). Natural Product Research, 23, 1274-1278. DOI: 10.1080/14786410701642532

Inderjit, K., Dakshini, M.M. (1998). Allelopathic interference of chickweed, Stellaria media with seedling growth of wheat (Triticum aestivum). Canadian Journal of Botany, 76(7), 1317-1321. DOI: 10.1139/ b98-159

Jezierska-Domaradzka, A., Kuźniewski, E. (2007). Allelopathic effect of water extracts of Capsella bursa-pastoris (L.) Medik and Stellaria media (L.) Vill. on germination and juvenile stages of Ocimum 
basilicum L. and Origanum majorana L. Annales Universitatis Mariae Curie-Skłodowska Sectio E, 62(2), 10-16. [In Polish]

Kitanov, G.M. (1992). Phenolic-acids and flavonoids from Stellaria-media (L.) Vill (Caryophyllaceae). Pharmazie, 47, 470-471.

Kunachowicz, H., Przygoda, B., Nadolna, I., Iwanow, K. (2017). Tabele składu i wartości odżywczej żywności. Warszawa: Wydawnictwo Lekarskie PZWL. [In Polish]

Leblová-Svobodová, S., Kostír, J. (1962). Action of isothiocyanates on germinating plants. Experientia, $18,554-555$.

Liu, X.X., Wang, L., Wang, Q., Qiu, B. (2007). Chemical constituents from root of Psammosilene tunicoides. Zhongguo Zhong Yao Za Zhi, 32, 921-923.

Ma, L.H., Song, J., Shi, Y.Q., Wang, C.M., Chen, B., Xie, D.H., Jia, X.B. (2012). Anti-hepatitis B virus activity of chickweed (Stellaria media (L.) Vill.) extracts in HepG2.2.15 cells. Molecules, 17, 8633-8646.

Mikšátková, P., Ancheeva, E., Hejtmánková, K., Teslov, L., Lapč́k, O. (2014). Determination of flavonoids in Stellaria by high-performance liquid chromatography-tandem mass spectrometry. Analytical Letters, 47(14), 2317-2331. DOI: 10.1080/00032719.2014.908382

Nilsen, E.T., Orcutt, D. (1996). The physiology of plants under stress: abiotic factors. New York: John Wiley \& Sons, Inc.

Riece, E.L. (1984). Allelopathy. New York: Academy Press.

Sharma, A., Arora, D. (2012). Phytochemical and pharmacological potential of genus Stellaria: A review. Journal of Pharmacy Research, 5, 3591-3596.

Skrzypek, E., Repka, P., Stachurska-Swakoń, A., Barabasz-Krasny, B., Możdżeń, K. (2015). Allelopathic effect of aqueous extracts from the leaves of peppermint (Mentha $\times$ piperita L.) on selected physiological processes of common sunflower (Helianthus annuus L.). Notulae Botanicae Horti Agrobotanici Cluj-Napoca, 43(2), 335-342. DOI:10.15835/nbha43210034

Sturm, D.J., Kunz, Ch., Gerhards, R. (2016). Inhibitory effects of cover crop mulch on germination and growth of Stellaria media (L.) Vill., Chenopodium album L. and Matricaria chamomilla L. Crop Protection, 90, 125-131. DOI: 10.1016/j.cropro.2016.08.032

Turkington, R., Kenkel, N.C., Franko, G.D. (1980). The biology of canadian weeds.: 42. Stellaria media (L.) Vill. Canadian Journal of Plant Science, 60(3), 981-992. DOI: 10.4141/cjps80-141.

Yasukawa, K., Yamanouchi, S., Takido, M. (1982). Studies on the constituents in the water extracts of crude drugs. 4: On the roots of Stellaria dichotoma L. var. lanceolata Bge. Yakugaku Zasshi, 102, 292-294.

\section{Abstract}

The aim of the study was to investigate the allelopathic influence of Stellaria media (L.) Vill. on the germination and early stages of growth of commonly grown radish (Raphanus sativus L. var. radicula Pers.) in three cultivars: 'Rowa', 'Krakowianka', and 'Półdługa'. The aqueous extracts from fresh shoots of S. media in the form of: decoction, infusion, and macerate were prepared. The control group was radish seeds watered with distilled water. The germination capacity of radish seeds, seedlings growth, the fresh and dry mass of seedlings, and the degree of destabilisation of cell membranes were determined. This experiment showed that the germination of radish seeds was lower, independently of the type of $S$. media extracts used, compared to the control group. The lowest germination capacity was observed for the 'Rowa' cultivar on macerate, and the highest germination capacity was for 'Krakowianka' on decoction. On each of the extracts, the growth of 'Półdługa' seedlings was inhibited in relation to the control. In the other two cultivars, the growth of radish seedlings was stimulated by the infusion, and it was slightly inhibited by the decoction and macerate. The fresh mass of radish seedlings was lower on each extracts, compared to the control group. The exception 
was the 'Rowa' cultivar, for which the fresh mass of seedlings increased on macerate. The dry mass values for 'Rowa' and 'Półdługa' cultivars were lower than in the control, and, no significant differences were found for 'Krakowianka'. Compared to the control group, the applied extracts reduced the outflow of electrolytes through the cell membranes of radish seedlings of all the analysed cultivars. The exception was macerate, which caused an increase in the electrolyte leakage in the 'Rowa' cultivar.

Key words: chickweed, electrolyte leakage, germination rate, radish, seedling growth, weeds

Received: [2018.07.02]

Accepted: [2018.11.15]

\section{Allelopatyczny wpływ Stellaria media (L.) Vill. na kiełkowanie i wczesne etapy wzrostu Raphanus sativus var. radicula}

Streszczenie

W pracy podjęto próbę zbadania allelopatycznego oddziaływania Stellaria media (L.) Vill. na kiełkowanie i wczesne etapy wzrostu powszechnie uprawianej rzodkiewki (Raphanus sativus L. var. radicula Pers.) w trzech odmianach: 'Rowa', 'Krakowianka’ i 'Półdługa'. Sporządzono wodne ekstrakty ze świeżych pędów S. media w postaci: wywaru, naparu i maceratu. Grupę kontrolną stanowiły nasiona rzodkiewki podlewane wodą destylowaną. W doświadczeniu określono zdolność i szybkość kiełkowania nasion rzodkiewki, wzrost siewek, przyrost ich mas, stopień destabilizacji błon komórkowych. Eksperyment ten pokazał, że w porównaniu z kontrolą nasiona rzodkiewki kiełkują słabiej niezależnie od rodzaju zastosowanego wyciągu ze $S$. media. Najmniejszą szybkość kiełkowania zaobserwowano dla odmiany 'Rowa’ na szalkach z maceratem, a największą dla odmiany 'Krakowianka' na wywarze. Hamowanie wzrostu siewek stwierdzono u odmiany 'Półdługa' dla każdego z ekstraktów, w stosunku do próby kontrolnej. U pozostałych dwóch odmian napar stymulował wzrost siewek rzodkiewki, a wywar i macerat nieznacznie ograniczały przyrost na długość. Świeża masa siewek badanych odmian rzodkiewki była mniejsza dla każdego rodzaju wyciągu, w odniesieniu do kontroli. Odstępstwo od tego stanowi odmiana 'Rowa', dla której odnotowano przyrost świeżej masy siewek podlewanych maceratem. Wartości suchej masy dla odmian 'Rowa' i ‘Półdługa’ były mniejsze niż w kontroli, a dla 'Krakowianka' nie wykazano istotnych różnic. W porównaniu z kontrolą, zastosowane wyciągi zmniejszały wypływ elektrolitów przez błony komórkowe siewek rzodkiewki wszystkich analizowanych odmian. Wyjątkiem okazał się macerat, który u odmiany 'Rowa' powodował wzrost destabilizacji błon komórkowych.

Słowa kluczowe: gwiazdnica pospolita, wypływ elektrolitów, kiełkowanie, rzodkiewka, wzrost nasion, chwasty

\section{Information about authors}

Peiman Zandi https://orcid.org/0000-0003-3520-3994

He was intensely trained in agronomy (crop science) and specialising in stress physiology, biotic/abiotic stresses, and agroecology. He is also interested in working in different areas of plant developmental biology, agroecology, plant nutrition, botany, plant breeding, and genetics. His previous research project which was funded by Payame Noor University (Ganaveh, Iran) entitled 'Foliar application of ascorbate on the physiological and biochemical attributes of Iranian fenugreek (Trigonella foenum-graecum L.) landraces under drought stress'. Currently, he joined a research group at the Chinese Academy of Agricultural Sciences (Beijing, China) attempting to discern the possible function of iron plaque on chromium acquisition, accumulation, and translocation in selected rice (Oryza sativa L.) cultivars grown in different planting media. Their main aim is to verify the IP role in wetland plants subjected to Si fertilisation as an effective strategy to decrease $\mathrm{Cr}$ accumulation in O. sativa grown in Cr-contaminated environments.

Beata Barabasz-Krasny https://orcid.org/0000-0002-5800-6953

Her main scientific interests include floristics and phytosociology of non-forest plant communities with particular emphasis on the course of succession processes in the areas where agricultural activities were 
discontinued, the transformation of the plant cover of thermophilic swards, and the active protection of non-forest plant communities.

Alina Stachurska-Swakoń https://orcid.org/0000-0003-0381-4520

She is interested in the vegetation ecology, particularly in the mechanisms of changes in plant communities and flora under natural and anthropogenic influences.

\section{Joanna Puła}

Her research is connected with agrotechnology in plant cultivation and plant ecology. Presently, she is interest to use of biomass of plants and other organic fertilisers, like biochar, in agriculture.

Katarzyna Możdżeń https://orcid.org/0000-0002-5695-4474

Her scientific interests concentrate on the effects of different environmental factors (light, ozone, heavy metals, and allelopathic extracts) on the morphology and physiology of cultivated, protected, and invasive species of plants. 